\section{Tobacco consumption in Africa}

To the Editor-Dr Simon Chapman has demonstrated some interesting findings on changes in cigarette consumption per head in 128 countries. $^{1}$ There are, however, some anomalies which I find difficult to explain. Between 1986 and 1990 he shows a fall in per capita consumption of $9.3 \%$ for Africa, or $-2.26 \%$ per annum. This contrasts with an increased per capita cigarette consumption of $41.6 \%$ demonstrated by Masironi and Rothwell ${ }^{2}$ for Africa between 1970 and 1985, or $+2.6 \%$ per annum (and an increase of total consumption of $116 \%$ in the same period due to population growth). The Economic Intelligence Unit (Report No 2001, 1991) forecasts an increased total tobacco consumption for Africa of $70 \%$ between the years 1989 and 2000, which is about twice as large as the population increase of around $34 \%$ between 1990 and 2000 forecast by the United Nations Population Fund 1992. alies?

Can anyone explain these apparent anomKEITH BALL
London, UK

1 Chapman S. Changes in adult cigarette consumption per head in 128 countries, 1986-90. sumption per head in 128 countries,
Tobacco Control 1992;1: 281-4.

2 Masironi R, Rothwell K. Tendances et effets du tobagisme dans le monde. Rapp Trimest Statist Santit Mond 1988; 41 : 228-41.

In reply - As with my paper, ${ }^{1}$ Masironi and Rothwell ${ }^{2}$ used cigarette consumption data supplied by the US Department of Agriculture. However, their "Africa" differed from mine in that their list did not contain Egypt, Libya, Morocco, or Sudan (all tabled in their paper as Eastern Mediterranean countries and all of which - especially Egypt - had falls in per capita consumption for the later years that I examined). Their Africa also included the Central African Republic and Reunion - both of which showed a rise in consumption between 1970-85, while my Africa did not include these countries because of unavailable data.

Also, their method of calculating changes between the two years appears to have involved pooling the populations of all countries for 1970 and 1985 and then dividing the totals by the total consumption for all of Africa for both years. By this method, changes between the two years in countries with large populations could explain much of the variance for the whole continent. Changes in countries with smaller populations tend to get swamped in this process. Masironi and Rothwell do not supply the population data for the years 1970 and 1985 , so readers of their paper cannot analyse how much of their stated $41.6 \%$ growth for the continent is explained by growth in per capita consumption in particular countries. Eye-balling their African table though, consumption rose in Nigeria, Algeria, Kenya, and South Africa all populous countries.

The question we should ask is what is the most informative and useful way of expressing changes in per capita consumption. A single figure for a whole continent can camouflage huge variations between countries (eg, Cameroon rising $144 \%$ and Zimbabwe falling $53 \%$ between 1970 and 1985) and therefore in my judgment is not very useful. I believe it is far more meaningful to speak of particular countries. So in Masironi and Rothwell's African table, per capita consumption rose in 14 countries, fell in 12 , and remained unchanged in three. In my table (for the years 1986 and 1990), per capita consumption fell in 28 and rose in four.

Unfortunately I have not been able to examine the Economist Intelligence report Dr Ball mentions. However, as with my comments above on the pitfalls of aggregating dozens of diverse nations into labels such as "Africa," it is not difficult to imagine that some populous nations in Africa might be forecast to experience rapid growth in total cigarette consumption as a reflection of both large population increase and increased economic prosperity. Consequently, it is quite plausible to argue that total consumption for Africa as a whole might rapidly accelerate, while per capita consumption might simultaneously fall in a majority of countries (many of which have quite small populations), as indicated in my paper.

\section{SIMON CHAPMAN}

Deputy Editor

1. Chapman S. Changes in adult cigarette consumption per head in 128 countries, 1986-90. Tobacco Control 1992; 1 : 281-4.

2. Masironi R, Rothwell K. Tendances et effets du tabagisme dans le monde. Rapp Trimest Statist Santit Mond 1988; 41: 228-41.

\section{Reasons for seasons}

To the Editor - The beautiful spring weather in Perth today, 9th September 1993, prompts me to question what underlies your decision to identify issues of Tobacco Control according to the season of their appearance in the Northern Hemisphere.

Australia and New Zealand have both made notable strides in the areas of tobacco taxation and curtailment of tobacco promotion over recent years and both countries lie in the Southern Hemisphere. While it is true that, in the days of the sailing ships, journals published in the European summer did not reach the Antipodes until the southern summer, now that Qantas and Air New Zealand both have Boeing 747-400 aircraft (with most flights smoke-free), this is no longer the case.

In addition, we sons and daughters of rugged colonialists regard what Britons call "summer" as a distortion of the Queen's English.

Would you and your co-editors consider changing from (Northern) seasons to month of issue, or even just number of issue within a given volume? This will prevent a further headache when, as we all hope, the number of suitable manuscripts submitted to Tobacco Control grows to the point where you will be obliged to publish six issues each year.

KONRAD JAMROZIK University of Western Australia Department of Public Health, Nedlands, Western Australia

In reply - Thank you for your thoughtful letter about the beautiful spring weather in Perth in September. I am composing this reply on the 17 th of October, one week after a hail storm in my home town and a short time before we can expect our first snow. I appreciate your attention to detail in your reading of Tobacco Control, and I hope all of our readers review the pages and covers of the journal with the same diligence.

The first five issues of Tobacco Control were indeed identified by the month of issue.
Regrettably, production delays (typical of any new journal) and slow overseas postal delivery resulted in many subscribers receiving the journal a month or more after the month of issue. This circumstance made the issues appear somewhat dated on arrival and created concern among some subscribers that they might not have been receiving the journal. Therefore, we began to designate each issue by season, starting with the sixth issue (Summer 1993). The number of the issue within a given volume always appears on the cover of the journal.

When we made the change from month to season, we were certainly aware of the difference in seasons between the Northern and Southern Hemispheres. However, we anticipated that our Southern colleagues (who comprise about one-sixth of our readership) would understand and accept the designated season as pertaining to the site of publication.

The publisher and editors do hope that we will be able to publish Tobacco Control on a bimonthly or monthly basis in the years to come. When that happens, as you point out, we will have to drop our seasonal designation. Increasing the frequency of publication will require growth in two areas: 1) submission of high-quality manuscripts and material for other sections of the journal; and 2) the number of subscribers, which is the main determinant of the journal's budget. - ED

\section{How much does Ciba-Geigy really want} to reduce smoking?

To the Editor - In November 1993 an AllAfrica Conference on Tobacco Control focused on a number of broad issues and strategies required to prevent a future epidemic of tobacco-related death and disease in Africa. Funding support for the conference was sought from a wide range of African and international donor agencies including private pharmaceutical companies that the organising committee believed were committed to tobacco control. One of these was CibaGeigy, marketer of Nicotinell TTS.

In a response to our request for funding (sent in October 1992), the head of the Medical Department of Ciba-Geigy South Africa (Dr Heinrich Hoehler) commented that Ciba-Geigy had "expressed interest as a partial sponsor" for the conference. At that point we hoped that they had decided to provide support; only the extent of the support needed to be determined.

Over the next few months we provided them with the necessary detailed information; updated budgets and the programme. After repeated attempts (telephonically and in writing) to get a response, finally in May 1993, the head of the Pharmaceutical Division, Dr JG Niehaus, responded saying "In the marketing of our new product, Nicotinell TTS, we have had to take cognisance of the presence and activities of the tobacco lobby and a policy decision was taken early in the process to direct our efforts towards a positive goal of supporting and participating in community efforts to help smokers give up smoking, rather than setting ourselves on a head-on collision course with the abovementioned lobby." We felt that it was in their best interests to give them an opportunity to reconsider and in response to that request in July 1993, they finally commented that "... after length discussion it was decided to uphold our decision."

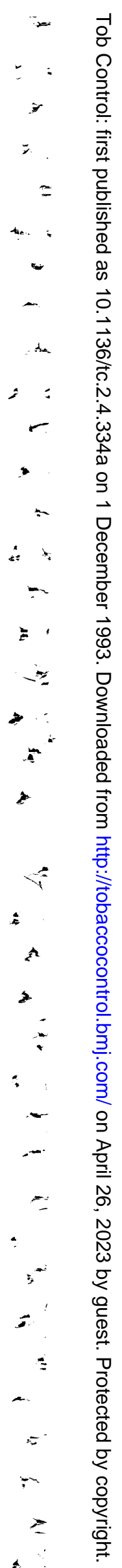

$\because$ 